\title{
Global Talent Management
}

Dr Oriaghe Raphael Oseghale

Swansea University,

Talent Bank Project

Swansea, SA2 8PP, Wales, UK

E-mail: 0.r.oseghalle@swansea.ac.ulk

Dr John Mulyata

Swansea University

School of Management

Swansea, SA2 8PP, Wales, UK

Email: j.muyalta@yahoo.com

Professor Yaw A. Debrah*

Swansea University,

School of Management

Swansea, SA2 8PP, Wales, UK

E-mail: y.a.debrah@swansea.ac.uk

*Corresponding author 
Reference As: Oseghale, R. O., Mulyata, J. and Debrah, Y.A. (2018) "Global Talent Management" in Machado, Carolina and Paulo, Davim (Eds.) Organizational Behavior and Human Resource Management, Springer.

\section{Global Talent Management}

Abstract Talent management (TM) is now firmly pursued by organisations globally as a strategic imperative. Although the present talent shortage is a global challenge, it is more critical in emerging economies, particularly in sub-Saharan Africa. The enormous challenges associated with the attraction, development and retention of talent by firms operating in subSaharan Africa (SSA) call for the adoption of robust talent management (TM) strategy to navigate these challenges. However, the extant literature on talent management has failed to examine in detail the talent management practices of organisations in Africa to feed into the stock of global knowledge on talent management. This chapter therefore provides empirical evidence on talent management with a contextual focus on Multinational Enterprises (MNEs) in a sub-Saharan African country.

\section{Introduction}

The increasing internationalisation of trade and business activities facilitated by globalisation has brought about opportunities, challenges as well as competitive pressures for firms to innovate and improve their competitive standing. Of course, these challenges and competitive pressures are due to the increasing number of companies operating in the global business scene, whose survival depends on performing better and more effectively than their competitors. Effective talent management (TM) is essential for firms to overcome challenges and to achieve a competitive advantage. Thus, an increasing body of scholarly work on TM underscores the view that only highly skilled and knowledgeable human resources can create and sustain a competitive advantage for firms [1]. Although all organisations have come to realise this fact, it is becoming increasingly difficult for Multinational Enterprises (MNEs) to find employees with the requisite talent to manage their numerous overseas subsidiary operations. Organisations are thus faced with a demand for talent that far exceeds the supply. As a result, organisations are now taking additional measures to attract, develop and retain the highly 
skilled workforce they require to strategically adapt and achieve a sustained competitive advantage [2].

As organisations intensify their efforts to secure a highly qualified workforce, the need to understand their global TM strategies and outcomes have also increased in importance. Although there is a growing body of knowledge on TM in the literature, there is some ambiguity as to how organisations manage their talent to gain and sustain a competitive advantage [3]. This is the case with all types of organisations including those in the private and public sector [4]. In this chapter, we seek to explore the global talent management practices of MNEs at the subsidiary level with a special reference to sub-Saharan Africa. Thus, the focus is on the attraction, development, evaluation and retention of talent in MNEs in sub-Saharan Africa. We believe that such an approach would illuminate our understanding of the problems, challenges and opportunities for talent management in sub-Saharan Africa (SSA). In fact, TM research is of great importance in the countries of sub-Saharan Africa due to the high demand for a highly skilled workforce and a shortage of talent. This is in line with Tatoglu, Glaister and Demirbag's [5] call for scholars to investigate further the contextual nature of TM practices in emerging economies. This, in turn, is rooted in the view that talent management practices are pursued and adopted by firms and are society-influenced and determined. Hence, in discussing TM, we draw on examples from Nigeria.

The rest of the chapter is organised as follows: the next section reviews the general literature on global TM with a specific focus on how it applies in the private sector. This is followed by a discussion of global talent management (GTM), practices, strategies and outcomes of MNEs in the Nigerian oil and gas industry. The penultimate section delves into the relevant skills' gap in organisations in sub-Saharan Africa and the need for talent development is analysed with pointers on how future research can help address the issues raised. The chapter concludes with some review questions. 


\section{Global Talent Management (GTM)}

Developing human resource competencies fit for the global market is the desire of many professionals and many organisations including MNEs who are equipping their employees with global skills. According to Sparrow, Hird and Cooper [6], this orientation has emerged from the human resource planning initiative which sprang up in the 80s and early 1990s and provided the 'intellectual' root of TM. This movement brought to the fore the need for HR forecasting, succession planning, the management of employees' needs as well as the development of employees' capabilities [7]. Thus, the concept of TM emerged around the late 1990s [8], with debates focusing on how organisations can attract, develop, manage and sustain a highly skilled and knowledgeable set of individuals [7]. In the view of Collings [9], TM is the development and management of high performing and high potential incumbents in critical organisational roles. TM activities are designed to create talent pools that feed particular job categories and focus on developing the individual competencies and behaviours that make such jobs and employees successful [10]. Here, the focus is more on developing a holistic, enterprisewide/organisation-wide talent mindset. Obviously, it is this enterprise-wide/organisation-wide talent mindset that mainly distinguishes TM from the traditional human resource development role.

At another level, it is asserted that economic globalisation has precipitated the emergence of GTM [7]. GTM focuses on the organisational strategies, policies and practices designed to attract, select, develop and retain highly skilled and knowledgeable employees to fill important roles in the organisation's global operations [11]. Thus, the first stage is to identify those pivotal roles that create added-value for the organisation and provide the focus for GTM which then makes plans to identify, select, retain and develop the abilities of the employees who will fill the roles [7]. 
It is well known that MNEs struggle to identify and hire the right people with the right skills to work in their organisations [12]. The chapter now turns to consider the literature relating to the various global talent management practices adopted by the MNEs in their quest to attract, develop and retain a highly skilled workforce in the long-term.

\section{Global Talent Management Practices}

The need for greater employee performance is creating a considerable interest in the use of different talent management practices among MNEs. In order to accomplish this task, MNEs adopt a range of global talent management practices pertaining to talent attraction, training and development, performance appraisal and retention. Obviously, only employers with high quality and effective TM practices will grab and retain a fair share of talent. We discuss these talent management practices in detail below:

\section{Attraction}

Talent attraction involves recruiting and selecting a highly skilled and knowledgeable workforce. Tarique and Schuler [14] observed that talent attraction can be discussed under three main headings: talent planning, employer branding/human resource reputation and talent sourcing.

Talent planning: talent planning or human resource planning precedes every hiring activity and helps to identify the global future talented needs of MNEs. Talent planning is very important at all levels of the organisation [14 15] and to be successful the aims and objectives of the company will need to be clearly defined and a deep knowledge of the market sourced [16]. It involves a detailed HR need forecast, HR demand forecast and an action programme of development [16]. Initially, a combination of both quantitative and qualitative methods of investigation (i.e. job analysis, HR audit, etc.) is used to create a snapshot of the existing workforce at various levels, i.e. qualification, skills and length of experience [16, 17]. A forecast of future skills need in the organisation is later carried out in order to identify any 
skills' mismatch [17]. This is followed by a talent sourcing programme designed to correct any skills' gap identified. Analysis and programme design depends on the use of existing human resource data (i.e. attrition and retirement rate of current employees) as well as the company's overall business strategy [14]. The goal is to have employees with company specific competencies at the right place at the right time with the needed motivation at all levels and locations of the MNEs [18]. However, some challenges have been identified with talent planning or HR planning. There may be a lack of reliable data to carry out an analysis of the existing skills' level of the current workforce. Besides, available data can also be manipulated for political reasons [17].

Employer branding: employer branding describes every effort made by employers/MNEs to communicate to both prospective and existing employees that their organisation is a desirable place to work in, thus, creating a compelling and distinctive employee value proposition [10]. Employer branding influences the impression applicants have regarding a MNEs's image as an employer. This perception or impression could be negative, neutral or positive. According to Jiang and Iles [10], MNEs should therefore view employer branding as a marketing function and treat potential applicants as customers. Accordingly, MNEs analyse the strategies of rival companies and develop and communicate an employee value proposition which portrays the company as an employer of choice to specific applicants [19]. MNEs effectively brand themselves as employers of choice in order to compete for scarce talent by increasing start-up wages/incentives, designing/providing jobs that are more engaging and flexible, providing training and career development opportunities, treating employees with respect, providing good work-life balance, providing performance pay and being more socially responsible, etc. [20-22]. Career growth, challenging work, performance and a value-driven organisation are some of the attributes which talent view as important when looking for the ideal employer [23]. Indeed, job candidates are more attracted to firms with benefits that align with their inherent 
needs and preferences [24]. The reason is that an individual's motivation is shaped by needs and people are attracted to a source that could fulfil their needs [25].

Talent sourcing involves the recruitment and acquisition of a highly skilled and knowledgeable workforce who can create added-value for MNEs and their subsidiary operations. The challenge for MNEs is how to reach this set of highly skilled and knowledgeable people who are mostly in employment. In addition, MNEs are faced with the challenge of countering the threat of talent being more attracted to domestic firms rather than MNEs [26]. Thus, MNEs adopt diverse creative strategies to target different talent groups from the external labour market and they include: university career fairs (specifically for hunting foreign nationals who can be deployed to work in their home country), targeting a specific individual profile on social network, i.e. LinkedIn, Myspace etc., and attracting a section of the society not fully represented in employment and providing the support they need to manage career barriers, i.e. female workers [27, 28]. MNEs also target talent through consultant groups, informal network ties, i.e. retired employee groups, referral by existing employees and professional bodies. However, fair employment agencies, i.e. the British Equality and Human Rights Commission (BEHRC), frown at informal recruitment as this may lead to the perpetuation of one dominant group in the workforce [29].

After targeting highly skilled and knowledgeable job applicants through the various approaches above, MNEs adopt different external talent selection strategies to identify the most qualified. These strategies include: analysis of application, psychological test, assessment centres and interviews with managers [29]. According to best definition of talent, it is the exceptional and unique psychological qualities that constitute talent [30]. It therefore would seem that psychological tests (personality, competence and aptitude tests) would be very helpful in identifying a candidate as 'talent'. In global talent management practices, identifying talent for future positions should be based on assessment of personal skills such as the ability to learn 
communication skills, flexibility, adaptability and entrepreneurship skills [30]. It is important to note, however, that the skills MNEs assess job candidates for during selection may differ from one organisation/industry to the other.

In addition, MNEs may also fill their vacant positions internally by hiring from their existing pool of employees. Talent selection strategies in this regard could include: goal achievement assessments and work performance assessment [30]. Overall, MNEs need to tread with caution in their selection process in order not to discriminate against certain groups of people, i.e. ethnic minorities, women and people with less ability in the society [29]. Of course, employment laws in many societies deter organisations from discriminating against any group or section of the society [31], as this may lead to an adverse impact - the selection of more majority persons than minority persons [29]. Thus, MNEs will need to identify and adopt selection methods that do not create any form of adverse impact.

With the advent of advanced technology, talent identification, recruitment, application process, sifting through applications and the selection process can be carried out electronically over the Internet [29]. Obviously, conducting the employment process through electronic means make the entire process far quicker and less cumbersome.

\section{Training and development}

After hiring a job applicant or putting a candidate in a talent pool, the next stage is 'polishing the rough diamonds' through various training and development schemes [30]. Talent development can be defined in a variety of ways but according to [32]:

'Talent development focuses on planning, selection, and implementation of development strategies for the entire talent pool to ensure that the organisation has both the current and future supply of talent to meet strategic objectives and that development activities are aligned with organisational talent management processes.'

This involves providing training for the different talent groups, i.e. a management talent group, a technical talent group and other professional talent groups, in order to meet their current and 
future skills' need in the various international operations of MNEs. The talent development process comprises of four broad areas: identifying the need to train and who to train; design (i.e. what training programmes can develop what competencies); evaluation (i.e. what tool can be used in measuring training effectiveness); and organisational support for training. Although this process may vary from one MNE to another; training has to be aligned with the goals of the organisation [33, 34]. Existing research suggests that large MNEs with standardised services/products, global HR policy and operate in the low technology/low cost sectors are more likely to use talent development for their high potential employees [35]. In addition, talent development is also important for MNEs with a good human resource reputation as well as MNEs seeking to develop local talent $[36,37]$.

MNEs (as well as domestic firms) develop a range of competencies, i.e. technical, behavioural and cross-cultural skills through their various talent development programmes, depending on the skills' need of the company [38]. They adopt a range of developmental experiences and practices such as global assignments, participation in global teams, cross-cultural training, short courses/programmes and coaching/mentoring in developing these competencies among their employees. In most MNEs, training programmes are personalised to meet the individual training and development needs of the employees. Training could be conducted on- and/or offthe-job by managers internally and/or externally by various external bodies, i.e. a consultant group. The decision to conduct on-the-job training and/or off-the-job training depends on the types of skills to be developed, whether the company has the resources (in terms of managerial skills, transmission abilities and facilities) to offer training internally and whether the employees have the time to go for external of-the-job training.

Many MNEs also have global leadership development programmes for developing a pool of future leadership/management talent. The primary goal of these global leadership development programmes is to stretch the minds of employees with leadership potentials beyond narrow 
domestic borders. Approaches for developing global leaders in MNEs include altering existing traditional training approaches such as executive coaching, 360-degree feedback, job assignment, action learning, outdoor experiences, mentoring and networking, etc. [39]. Of course, an important challenge is whether MNEs can modify their traditional training approaches appropriately to address the leadership development goals. Adapting what used to be general training methods requires a change of strategy; for instance, mentoring is more effective if a less experienced manager is being guided by someone with sufficient international work experience. In the same vein, action learning programmes will be more effective if employees from different countries, i.e. global teams, are grouped together and tasked with the responsibility to analyse global operations of the company. Other global leadership training and development strategies used by MNEs include participation in corporate projects, participation in international projects, job rotation, international assignments and internships abroad [30].

However, it is important to note that context plays an important role in determining the design, nature and extent of effective training [14]. In Germany, for instance, firms invest heavily in the training and development of employees. These firms work together in unison and agree not to free-ride [40]. Moreover, MNEs are expected to pay great attention to contextual issues in the design and implementation of their training and development programmes in their different subsidiary locations.

\section{Performance evaluation}

To ensure that talent management achieves its goals, MNEs need to evaluate talent performance outcomes to allow corrections to be made in the advent of poor performance outcomes resulting from an ineffective talent management process. MNEs evaluate their talented employees' performance outcomes on a periodic (i.e. annually, bi-annually and quarterly) basis to ascertain their contributions towards organisational success as well as to 
verify their development/progression potential for their next career level [41]. Performance is usually measured against measurable performance dimensions [42] identified by functional heads or collaboratively between managers and employees [43].

Talent performance is usually evaluated by the line manager. Performance can also be evaluated by colleagues, employee self-appraisal or a consultant group [16]. In recent times, however, most MNEs now adopt the 360-degree option where all stakeholders (colleagues, customers, line managers and senior managers) having a work relationship with the employee being appraised are involved in the appraisal process. The approaches used when evaluating talent performance could be quantitative, i.e. using a behavioural anchored rating scale, critical accident technique, graphic rating scale, etc.; or qualitative, i.e. using assessment tests/exercise and/or observing highly skilled employees on-the-job, in nature [31, 44]. Whilst no one approach is best, employees and their managers should design a workable system and create a good sense of ownership [45]. Indeed, collaborative goal setting provides specific and measurable goals for all parties involved in the appraisal process [43].

The outcomes of talent performance appraisal often translate into employee promotion, transfer, career planning and development and changes in remuneration, in most MNEs [30, 46]. Of course, high performers advance to their next career level, whilst under-performers might be encouraged to leave [47] after undertaking a couple of training sessions without improvement in subsequent appraisals. MNEs are, however, guided by institutional regulations when taking decisions on whether to lay-off employees using performance evaluation outcomes as this may not be acceptable in some countries. Arguably, although performance appraisal is becoming pervasive worldwide, cultural and institutional influences impact on how they are designed and implemented in different parts of the world [48]. However, the 'up-orout' career advancement model identifies and retains the highest performing employees for MNEs [41] when used correctly. 
Although, talent performance appraisal is increasingly gaining popularity across MNEs [49], an important challenge related to performance appraisal is that of a rating bias. A rating bias can be in the form of leniency, i.e. a tendency to overate performance or a halo-effect which reflects exaggerated correlations among ratings based on disparate criteria [41]. Regardless of the rating biases, performance appraisal should be included in talent management practices because it provides information on employee and organisational performance. Moreover, performance evaluation addresses a broad differentiation of performance and talent among employees [41]. To address any performance appraisal bias, many MNEs provide pre-appraisal training for managers and their subordinates. Pre-appraisal training provides both parties with the relevant information on what is expected in the appraisal process [16].

\section{Retention}

Once the talent has been hired and their 'rough edges' have been smoothed through various talent development initiatives, MNEs strive to retain them in the long-term. This is particularly the case if an employee is seen to be presently performing in her/his present role or having the potential to create added-value for the company in future. Obviously, it is very difficult to locate and nurture talent, but quite easy to lose them [50], thus, talent retention activities involve various policies and practices MNEs put in place/undertake to prevent talented employees from leaving voluntarily [14]. MNEs undertake this task in order to reduce the challenge of losing their highly skilled and knowledgeable employees and their human capital to rival organisations [14]. The existing scholarship on talent management suggests that effective retention strategies in MNEs include talent engagement, career development and a talent management culture [14].

Talent engagement may not have a generally accepted definition but is often defined as emotional and intellectual commitment to the organisation or the amount of discretionary efforts exhibited by employees on-the-job [51]. The existing talent management literature 
suggests that talented employees who are engaged with their organisation and work are more likely to be satisfied, have a positive opinion about their employer/organisation, display more loyalty to customers, display better work performance and are less likely to leave the company voluntarily [14]. According to an ISR [52] report, three global factors are important for managing engagement and they include: career development, leadership and empowerment. MNEs with high levels of engagement provide talented employees with opportunities to develop their human capital in order to realise their potential [52]. The logic here is that talent is more likely to invest in their jobs/organisations when their organisation is first to invest in their career. Existing studies also suggest that promotion to a leadership position also helps to engage employees [52]. The thinking is that leadership positions attract higher pay, autonomy, authority and access to information, growth opportunities and resources, etc. which employees value [51]. In addition, getting talented employees involved in the decision-making process also helps to keep them engaged. Obviously, managers of highly-engaged organisations do not create blame or fear cultures [51]. Consequently, employees express their ideas as well as views freely.

Career development: organisations that support their talented employees through career planning as well as design career development programmes to help them achieve their career aspirations are more likely to experience low levels of voluntary employee turnover [14]. Employees with a more detailed understanding of their career path and the assurance that their organisation values their training and career development are more connected to their jobs and the organisation where they work. Thus, training as well as opportunities for career growth are important retention strategies in MNEs.

Talent management culture: in an ever shrinking global talent pool, organisations adopt talent management to retain their talent, although, many organisations lose out by not developing and maintaining their talent management correctly [23]. Indeed, most MNEs are ineffective in 
developing, maintaining and aligning their talent management efforts correctly [15]. A strong talent management strategy serves as an enticement for talent in today's competitive business environment. MNEs with a good record of talent managing all employees, sourcing talent globally as well as rewarding managers for improving talent retention, are more likely to have their employees engaged [53]. Of course, a good talent management culture will suggest to the talented employees that their company values them and this helps to gain their support and commitment to both their job and organisation. Arguably, when MNEs honour their job promises to employees as publicised during job adverts, the employees will be happy to commit themselves to their jobs/organisation as well as remain with the organisation in the long-term.

\section{Global Talent Management in Africa}

In this section, we draw on empirical evidence from a study on Talent Management in MNEs in the Nigerian oil and gas industry to illustrate the challenges in GTM [54]. The case specifically looks into graduate talent management in three leading MNEs whose business activities cut across refining, marketing and distributing refined petroleum products in Nigeria and beyond [54].

The MNEs have graduate programmes in place for the management of their new management graduate hires; making the companies interesting sites to explore and understand the challenges linked with GTM. Overall, the companies have between one hundred and fifty to five hundred workers across various functions on their payroll. These employees comprise of mostly locals and a few expatriate workers because of the workforce localisation policy in operation in Nigeria which expects oil and gas MNEs to employ 75 per cent of Nigerians in managerial and other professional roles after ten years of being granted the licence to operate in the industry.

Two of the three MNEs are international oil and gas companies operating in Nigeria with headquarters in France and the United States, the third MNE is a national oil and gas company with subsidiary operations in Ghana and Togo. The case adopts a double source of informants- 
human resource managers/senior manager/line managers in charge of managing the talent and the management talent themselves; to create a more detailed understanding of GTM in the Nigerian oil and gas industry context. The sources of evidence/data include interviews with managers, management talent survey and published reports on the case study's companies. In this chapter, we refer to the case study companies as the case study firms/MNEs to conceal their identity and protect their privacy.

The study sought to explain how the three oil and gas MNEs in Nigeria attract, develop and retain their stocks of new management graduate employees for the wider development of talent and management in the companies. Below we provide the pertinent parts of the study to enhance our understanding of GTM practices and challenges.

The study revealed that both the management and the employees had divergent views on the purpose of the GTM initiative. From the management's perspective, TM was seen as a means of identifying, developing and retaining talent for the purpose of meeting organisational goals, whilst, individual employees saw it more from an altruistic perspective as a means of career development/career progression and salary increments. However, the finding of the study seems to suggest that TM in this context benefited the organisations, the talented employees as well as the host communities where the organisations operate. It was mentioned over and over again that undoubtedly the organisations suffer a loss when trained highly skilled employees leave and take their company specific human capital to rival firms.

In line with the definition of GTM by Collings [9], TM programmes in the oil and gas MNEs in Nigeria are aimed at managing all the management talent recruited into the management development programme implying long-term careers in the various departments which cuts across the organisation such as marketing, HR, finance, legal services, operations and logistics. Thus, graduate employees who are not recruited into the management development programme 
(for instance, contract workers) were often not considered for the company TM programme. As such, they were also not entitled to the same benefits, i.e. competitive pay, career promotion opportunities, etc. enjoyed by those on the companies' talent management programmes.

Generally, the three case study MNEs employ about 20 employees once in two years. Hiring in the case study companies is developed in a systematic way to ensure that those employed secure the required opportunities for a long-term career. Thus, the companies often ensure that they hire graduates when there are job openings that will lead into a long-term career with the companies.

In terms of how the case study companies sourced for talent, recruitment strategies in the oil and gas MNEs used various strategies including walks-in, advert on the companies' online portal, newspaper advertisements and through headhunters. In view of the lack of penetration of the Internet in Nigeria, the MNEs relied on newspaper advertisements to reach a wider pool. In parallel, the companies used headhunters when the firm anticipates that its human resource staff would be overwhelmed with applications and hence throwing up huge challenges in shortlisting and interviewing. In the industry, it is not uncommon for the job applicants to undergo three different assessment levels before employment. As a first step, qualified shortlisted graduate applicants are invited to take an aptitude test with the companies. The successful applicants are invited to an assessment centre for further assessment. Those selected after the assessment centre screening are further invited for an in-house interview with HR and senior managers. In all levels of assessments, the companies assess applicants for attitude and the soft skills required to perform well. Finally, successful interviewees are offered employment with the companies.

Generally, the case study MNEs in the oil and gas industry do not encounter challenges in attracting management talent in Nigeria. This is because the companies have successfully 
branded themselves as employers of choice through their competitive wages, performancerelated pay, career development opportunities, retirement benefits and training and development programmes for highly talented employees. As a result of these perceived benefits, a large number of Nigerians prefer to seek employment within what they consider as a lucrative industry. Nonetheless, in some cases, the companies promised too much during job advertisements as indicated by some of the graduate employees surveyed. The employees indicated that graduate employee programmes in the companies fall short of their expectations as promised in the companies' job advertisement. In spite of this, there is no shortage of applicants for management development positions in the MNEs.

Nevertheless the managers who participated in the study pointed to the challenges associated with sourcing for some categories of engineering talent such as petroleum engineers, rig engineers, etc. In response, the companies undertake industry-education outreach programmes to address the perceived talent shortage in these areas. In some cases, the companies provide learning support to the universities to teach their undergraduate students in the relevant subject areas or sponsor selected students through university (abroad or locally) to enable them to acquire the relevant skills. In some other cases, the companies provide the opportunities for students to take up an attachment to learn industry relevant skills in the subject areas for a short period of time.

Upon assumption of duty, the case study organisations develop the competencies of their new employees through on- and off-the-job training. In the case study MNEs, training strategies adopted include rotational assignment, in-class courses, online computer-based training and mentoring programmes. Training programmes were usually internal and/or external in all the organisations and training activities were aimed at meeting both the skills' needs of the organisations as well as those of the highly skilled employees. Accordingly, training 
programmes were designed to help employees develop the managerial capabilities, soft skills and the technical skills required to perform well in the companies.

The case study companies appraise the performance of their highly skilled and knowledgeable employees bi-annually to assess their individual performance as well as their contributions to company goals. According to the managers interviewed, TM impacted the performance of employees' significantly in the case study organisations.

The case study organisations seek to retain their highly talented employees through various retention strategies. In the case study MNEs, the employees are offered competitive pay, individual performance pay, employee retention scheme, training and development opportunities, career development opportunities, housing benefits, transport benefits, complete healthcare insurance for employees and their families and a retirement package. In fact, some of the oil and gas MNEs studied had previously been rated among the best place to work in Nigeria because of the many benefits associated with working with them. Thus, the retention rate is high in the companies (above 95 per cent). The few employees who leave/exit the firms in their mid-career often leave to start-up a business for themselves, relocate to other countries, gain employment with a more reputable oil and gas MNE or retire from work. However, some of the employees wanted improvement in the companies' talent management processes, i.e. training and development programmes, even though they wanted to stay with the companies in the long-term because of the excellent career and promotion opportunities. Overall, it was concluded that GTM in the case study MNEs in the oil and gas sector in Nigeria is very successful in view of their talent development efforts as well as staff retention levels [54].

\section{Practical implications}

At this juncture, it is appropriate to discuss the practical implications of the issues discussed in this chapter. From the preceding discussions, it is clear that practising managers have a number of lessons to learn from the experience of these multinational companies. It is suggested that 
to be able to attract and retain suitably qualified talent in the long-term, practising managers must design and implement robust talent management strategies that provide future career promotion opportunities for employees. In consonance with existing studies, career promotion opportunities help to engage employees [52]. The idea is that promotion to leadership positions attracts higher pay, autonomy, authority and access to information, growth opportunities and resources, etc. which employees value [51].

In spite of a successful talent management practice in the case study MNEs, the dearth of talent within the industry's relevant skills still persists as identified by Osabutey et al. [1]. In line with the present talent shortage in the SSA context and the associated TM challenges faced by organisations operating in this environment, a vibrant global talent management initiative is required by MNEs as well as government agencies/institutions to address the problem. Indeed, only a vibrant talent management initiative by all firms operating both in the public and private sector in Africa can help reduce the present talent deficit. Of course, anything short of an effective talent management strategy will mean that the present talent shortage and the competition for talent among firms in the sub-Saharan Africa context will persist. According to Ibeh and Debrah (2011), one way of tackling this shortage is for MNEs and other private sector firms to tap into the under-utilised pool of female talent. We add that all firms should henceforth engage in industry-education outreach programmes to help address the pressing talent shortage in countries in sub-Saharan Africa. This is something that some MNEs in the oil and gas industry in Nigeria are already doing very well. For example, Shell Petroleum and Chevron Nigeria Plc offer scholarships to several young Nigerians to study at a Master's degree level abroad. We call on the other firms as well as public sector organisations/institutions to take up the same challenge in trying to address the present talent shortage problem in subSaharan African.

\section{Conclusion}


This chapter has discussed talent management activities and outcomes from a global perspective but with a special focus on sub-Saharan Africa. The extant literature acknowledges the need for more contextual studies on talent management initiatives and practices. This chapter provides insight into how organisations manage their talent in the context of subSaharan African. The study specifically provides insights into GTM in MNEs operating in the sub-Saharan African country of Nigeria, an area that is well under-researched in the literature on GTM. The findings suggest that whilst TM is very successful in the MNEs, talent shortage in sub-Saharan Africa still persists. To reverse this trend, it is suggested that organisations/firms operating within the SSA context must endeavour to design and implement vibrant TM programmes to address the recruitment, selection, development and retention challenges associated with the present talent shortage in Africa.

\section{Review Questions (Answer True or False)}

(1) With reference to Vaiman, Scullion and Collings' (2012) work, GTM focuses on the organisational strategies, policies and practices that are designed to attract, select, develop and retain highly skilled and knowledgeable employees to fill important roles in the organisation's global operations

(2) Talent attraction involves workforce planning, employer branding and talent sourcing activities carried out by organisations to employ the highly skilled and knowledgeable employees required to create added-value

(3) On-the-job and off-the-job training programmes are vital for employees to acquire the relevant competencies required to perform well in MNEs

(4) TM is practised in only MNEs

(5) The long-term talent retention strategies adopted by MNEs include the development of a talent management culture, career development opportunities, employee engagement and abuse and exploitation of employees 
Please see the answers at the end of this chapter after references.

\section{References:}

1. Osabutey, E., Nyuur, R. B. and Debrah, Y. A. (2015). Developing strategic international human resource capabilities in Sub-Saharan Africa. In C. Machado, (ed.), International human resource management. London: Springer, pp.37-51.

2. Reis, R. S. and Quental, C. (2014). Global talent management in Brazil: Jeitinho as a managerial talent. In A. Al Ariss, (ed.), Global talent management: Challenges, strategies and opportunities. New York, London: Springer.

3. Al Ariss, A. (2014). Global talent management: An introduction and a review. In A. Al Ariss, (ed.) Global talent management: Challenges, strategies and opportunities. New York, London: Springer.

4. Poocharoen, O. and Lee, C. (2013). Talent management in the public sector: A comparative study of Singapore, Malaysia and Thailand. Public Sector Review, 15, pp.1185-1207.

5. Tatoglu, E., Glaister, A. J. and Demirbaja, M. (2016). Talent management motives and practices in an emerging market: A comparison between MNEs and local firms. Journal of World Business, 51, pp.278-293.

6. Sparrow, P., Hird, M. and Cooper, C. (2015). Do we need HR? Repositioning people management for success. London: Palgrave MacMillan.

7. Cascio, W. F. and Boudreau, J. W. (2016). The search for global competence: From international HR to talent management. Journal of World Business, 51, pp.103-114.

8. Michaels, E., Handfield-Jones, H. and Axelrod, B. (2001). The War for talent. Boston: Harvard Business School Press.

9. Collings, D. G. (2014). Towards mature talent management: Beyond shareholder value. Human Resource Development Quarterly, 25(3), pp.301-319.

10. Iles, P., Chuai, X. and Preece, D. (2010). Talent management and HRM in multinational companies in Beijing: Definitions, differences and drivers. Journal of World Business, 45, pp.179-189.

11. Vaiman, V., Scullion, H. and Collings, D. (2012). Talent management decision-making. Management Decisions, 50(5), pp.925-941.

12. Devine, M. and Powell, M. (2008). Talent management in the public sector. The Ashridge Journal, Autumn 2008.

13. Scullion, H., Collings, D. G. and Caligiuri, P. (2010). Global talent management. Journal of World Business, 45, pp.105-108.

14. Tarique, I. and Schuler, R. (2012). Global talent management. Literature review for the Society of Human Resource Management Foundation for publication, Autumn 2012.

15. Cheese, P. (2010). Talent management for a new era: What we have learned from the recession and what we need to focus on next. Human Resource Management International Digest, 18(3), pp.3-5.

16. Machado, C. (2016). Human resource management: An operational perspective. In C. Machado, C, and J. P. Davim, (eds.) MBA - Theory and application of business and management principles, London: Springer.

17. Beardwell, I. (2004). Human resource planning, in Beardwell, I., Holden, L. and Claydon, T (eds.) Human resource management: a contemporary approach $\left(4^{\text {th }}\right.$ ed.). London, New York: Prentice Hall.

18. Guthridge, M., McPherson, J. R. and Wolf, W. J. (2009). Upgrading talent. The McKinsey Quarterly(1), p.61. 
19. Hieronimus, F., Schaefer, K. and Schroder, J. (2005). Using branding to attract talent. The McKinsey Quarterly, (3), pp.12-14.

20. Amankwah-Amoah, J. and Debrah, Y. A. (2011). Competing for scarce talent in a liberalized environment: Evidence from the aviation industry in Africa. International Journal of Human Resources Management, 22(17), pp.3565-3581.

21. Gardner, T. M. (2005). Inter-firm competition for human resources: Evidence from the software industry Academy of Management Journal, 48, pp.237-256.

22. Hughes, J. E. and Rog, E. (2008). Talent management: A strategy for improving employee recruitment, retention and engagement within hospitality organizations. International Journal of Contemporary Hospitality Management, 20, pp.743-757, doi: 10.1108/09596110810899086.

23. Botha, A., Bussin, M. and De Swardt, L. (2011). An employer brand predictive model for talent attraction and retention. SA Journal of Human Resource Management/SA Tydskrif vir Menslikehulpbronbestuur, 9, Art. \#388, pp.1-12. http://dx.doi.org/10.4102/ sajhrm.v9i1.388.

24. Minchington, B. (2010). The employer brand manager's handbook. Torrensville: Collective Learning.

25. Armstrong, M. (2007). Employee reward management and practice. London: Kogan Page Limited.

26. Schmidt, C. (2011). The battle for China's talent. Harvard Business Review, 89

27. Hewlett, S. A. and Ripa, R. (2010). The battle for female talent in emerging markets. Harvard Business Review, 88,

28. Ibeh, K. and Debrah, Y. (2011). Female talent development and Africa business schools. Journal of World Business. 46, pp. 42-49.

29. Cook, M. (2016). Personnel selection: Adding value through people - a changing picture. (6 ${ }^{\text {th }}$ edn.). London: Wiley Blackwell.

30. Przytulai, S. (2014). Talent management in Poland: Challenges, strategies and opportunities. In A. Al Ariss, (2014). Global talent management: Challenges, strategies and opportunities. London, New York: Springer.

31. Bratton, J. and Gold, J. (2007). Human resources management: Theory and practice. (4 ${ }^{\text {th }}$ edn.). London: Palgrave Macmillan.

32. Garavan, T. N., Carbery, R. and Rock, A. (2012). Mapping talent development: Definition, scope and architecture. European Journal of Training and Development, 36(1), pp.5-24.

33. Johnson, J. P., Lenartowicz, T. and Apud, S. (2006). Cross-cultural competence in international business: Toward a definition and a model. Journal of International Business Studies, 37(4), pp.525-543. doi: 10.1057/palgrave.jibs.8400205.

34. Stewart, J. and Harte, V. (2010). The implications of talent management for diversity training: An exploratory study. European Journal of Training and Development, 34(6), pp.506-518.

35. McDonnell, A. (2011). Still fighting the 'War for Talent'? Bridging the science versus practice gap. Journal of Business and Psychology, 26(2), pp.169-173.

36. Kucherov, D. and Zavyalova, E. (2012). HRD practices and talent management in the companies with the employer brand. European Journal of Training and Development, 36(1), pp.86-104.

37. Petison, P. and Johri, L. M. (2007). Developing local talent in international subsidiaries: The importance of trust and respect in Toyota. Development and Learning in Organizations, 21(3), pp.10-13.

38. Crossman, J. E. and Clarke, M. (2010). International experience and graduate employability: Stakeholder perceptions on the connection. Higher Education: The International Journal of Higher Education and Educational Planning, 59(5), pp.599-613.

39. Oddou, G. R. and Mendenhall, M. E. (2008). Global leadership development. In M. E. Mendenhall, A. B. Osland, A. Bird, G. R. Oddou, and M. L. Maznevski (2008). Global leadership research, practice and development. New York: Routledge. 
40. Hall, P. A. and Soskice, D. (2001). Varieties of capitalism: The institutional foundations of comparative advantage. Oxford: Oxford University Press.

41. Lopes, S. A., Sarraguca, J. M., Lopes, J. and Duarte, M. (2014). A new approach to talent management in law firms: Integrating performance appraisal and assessment center data. International Journal of Productivity and Performance Management, 64, pp.523-543.

42. Doyle, M. (2004). Management development. In I. Beardwell, L. Holden and T. Claydon (eds.). Human resource management: A contemporary approach. $\left(4^{\text {th }}\right.$ edn. $)$. London, New York: Prentice Hall.

43. Sahai, S. and Srivastava, A. K. (2012). Goal/target setting and performance assessment tool for talent management. Procidia-Social and Behavioural Sciences, 37, pp. 241-246.

44. Ivancevich, J. M. (2007). Human resources management. (10 $0^{\text {th }}$ edn.). New York: Prentice Hall.

45. DeNisi, A. S. and Griffin, R. W. (2008). Human resources management. ( ${ }^{\text {rd }}$ edn.). New York: Houghton Mifflin Company.

46. Pocztowski, A. (2008). Zarza dzanie talentami w organizacji (pp.63-137). Krakó́w: Oficyna a Wolters Kluwer Business.

47. Stumpf, S. A. (2007). Stakeholder assessments as a predictor of high potential and promotion to partner in professional service firms. Career Development International, 12(5), pp.481-497.

48. Aguinis, H., Joo, H. and Gottfredson, R. K. (2012). Performance management universals: Think globally and act local, Business Horizons, 55, pp.385-392.

49. Fletcher, C. (2001). Performance appraisal and management: The developing research agenda. Journal of Occupational \& Organizational Psychology, 74(4), pp.473-487.

50. Mary, O. E., Enyinna, U. K. and Ezinne, K. M. (2015). The relationship between talent management and employee performance in Nigeria public sector: A study of selected firms in Delta State. International Journal of Economics, Commerce and Management, 3, pp.1581-1592.

51. Kular, S., Gatenby, M., Rees, C., Soane, E. and Truss, R. (2008). Employee employment: A Literature Review, Kingston Business School Working Paper Series, No. 9.

52. Towers Perrin Global Workforce Study, Executive Report (2005). Winning strategies for a global workforce, attracting, retaining and engaging employees for competitive advantage. (Online). Accessed from: www.towerperrin.com, accessed on: 15.05.2017.

53. Schuler, R. S., Jackson, S. E. and Tarique, I. (2011). Global talent management and global talent challenges: Strategic opportunities for IHRM. Journal of World Business, 46(4), p.506.

54. Oseghale, O. R. (2016). Talent management in multinational companies in the Nigeria oil and gas industry. Unpublished doctoral thesis.

\section{Answers to review questions}

1. True (please see the section on global talent management)

2. True (please see the section on talent attraction)

3. True (please see the section on training and development)

4. False (please see the section on performance appraisal)

5. False (please see the section of employee retention) 